\title{
Tingkat Eksistensi Elemen-Elemen Subak Sebagai Sistem Sosial

\author{
(Kasus Pada Subak Munggu Tegal Lantang, Desa Pererenan, \\ Kecamatan Mengwi, Kabupaten Badung)
}

\author{
PUTU CINTHYA WIRYANI PUDJA, I GEDE SETIAWAN ADI PUTRA, \\ WAYAN SUDARTA
}

\author{
Program Studi Agribisnis, Fakultas Pertanian, Universitas Udayana \\ JL. PB. Sudirman Denpasar 80232 \\ Email: cinthya.manyunk@yahoo.co.id \\ setiawanadiputra@rocketmail.com
}

\begin{abstract}
The Existence Level of Subak Elements as Social Systems

(A Case of Subak Munggu of Tegal Lantang, Village of Pererenan, Sub-District of Mengwi, Regency of Badung).
\end{abstract}

Subak or organization of irrigation system is a world cultural heritage which must be preserved, so that the existence of Subak should be maintained. The purpose of this study was to determine the level of the existence of the elements of Subak as social systems that includes goals, beliefs, feelings or sentiments, norms, sanctions, position and role, power, social rank, facilities, and area. The study took place in Subak Munggu Tegal Lantang by the number of respondents of 33 people. Data were collected by interview and analyzed descriptively and qualitatively. The results showed that the level of existence of elements of Subak as a social system was very high with a score of $85,86 \%$. It can be seen from the ten elements of a sociological approach. Indicators of interest was very high with a score of $89,70 \%$, confidence was very high with a score of $89,70 \%$, feeling was quite high with a score of $72,73 \%$, norm was very high with a score of $89,09 \%$, sanction was very high with a score of $86,46 \%$, position and role were very high with a score of $90,15 \%$, power was very high with a score of $84,04 \%$, social rank was very high with a score of $89,29 \%$, facilities were high with a score of $77,17 \%$, and area was very high with a score of $90,30 \%$.It is recommended that the Subak needs to strengthen some of the parameters of the weak indicators, i.e. the norms (awig awig, pararem) should be made in the written rules to suppress the land conversion to other uses, and it should pay more attention to its problem such as the pest attacks.

Keywords: existence, cultural, social system, element, and sosial interaction 


\section{Pendahuluan}

\subsection{Latar Belakang}

Subak merupakan salah satu pilar penyangga kebudayaan Bali, dan dapat dikatakan bahwa budaya subak telah mendominasi kebudayaan Bali (Pitana, 2003). Subak merupakan sistem irigasi yang berbasis petani dan lembaga yang mandiri (Sutawan, 2008). Pada dasarnya subak memberi pengaruh pada intensitas ataupun aspek kedisiplinan khususnya bagi para petani.

Subak memiliki peran penting dalam menekan alihfungsi lahan, sehingga eksistensi subak harus terus dipertahankan. Eksistensi subak dapat bertahan dengan baik apabila keanggotaan subak dapat menjalankan elemen-elemen subak. Elemenelemen tersebut meliputi, (1) tujuan, (2) kepercayaan, (3) perasaan atau sentimen, (4) norma, (5) sanksi, (6) kedudukan dan peranan, (7) kekuasaan, (8) jenjang sosial atau pelapisan sosial, (9) fasilitas, dan (10) wilayah. Masing-masing elemen tersebut memiliki fungsi yang berbeda, namun saling berkaitan dan merupakan satu kesatuan yang memiliki suatu tujuan tertentu.

Dinamika sektor pariwisata terus menggeser sektor pertanian secara perlahan dapat mengancam kelestarian dari eksistensi organisasi petani seperti subak.Jika subak sampai hilang, maka dikhawatirkan kemungkinan kebudayaan Bali akan terdegradasi.Oleh karenanya diperlukan adanya suatu institusi yang dapat mengkombinasikan aturan-aturan formal dan norma-norma religious secara operasional, sebagaimana yang telah berlaku dalam subak (Windia, 2006).

Subak Munggu Tegal Lantang sendiri merupakan salah satu subak yang terdapat di kawasan pariwisata. Jika Subak Munggu Tegal Lantang tidak mampu mempertahankan eksistensi dari elemen-elemennya secara keseluruhan, maka tidak menutup kemungkinan akan mengakibatkan terancamnya keberadaan serta kelestariannya. Oleh sebab itu perlu dikaji dan diteliti sejauh mana tingkat eksistensi dari elemen-elemen subak sebagai sistem sosial.

\subsection{Tujuan Penelitian}

Tujuan penelitian ini untuk mengetahui:tingkat eksistensi dari masing-masing elemen subak sebagai sistem sosial di Subak Munggu Tegal Lantang.

\section{Metode Penelitian}

\subsection{Lokasi dan Waktu}

Penelitian dilakukan di Subak Munggu Tegal Lantang dengan alamat pabrik di Desa Pererenan, Kecamatan Mengwi, Kabupaten Badung. Penelitian dilaksanakan dari bulan Februari 2016 s.d Mei 2016.

\subsection{Populasi, Responden, dan Informan Kunci}

Populasi dalam penelitian ini adalah anggota petani aktif di Subak Munggu Tegal Lantang berjumlah 222 orang.Responden merupakan orang-orang yang merespon atau menjawab pertanyaan penelitian baik tertulis maupun lisan (Arikunto, 
2003). Responden penelitian meliputi petani yang menjadi anggota aktif berjumlah 33 orang. Penentuan responden menggunakan teknik proportional random samplingyakni pengambilan sampel secara proporsi yang dilakukan dengan mengambil subyek dari setiap wilayahditentukan seimbang dengan banyaknya subyek dalam masing-masingstrata atau wilayah (Arikunto, 2006).Informan kunci dalam penelitian ini adalah Pekaseh Subak.

\subsection{Jenis dan Sumber Data}

Jenis data dalam penelitian ini meliputi data kualitatif dan kuantitatif. Sumber data terdiri atas data primer dan data sekunder. Data primer adalah data yang diperoleh dengan survei lapangan yang menggunakan semua metode pengumpulan data, sedangkan data sekunder adalah data yang telah dikumpulkan oleh lembaga pengumpulan data dan dipublikasikan kepada masyarakat pengguna data (Kuncoro 2003). Data primer diperoleh langsung dari responden meliputi jawaban responden dari kuesioner yang diberikan, serta hasil wawancara dengan Pekaseh Subak. Data sekunder diperoleh melalui studi literatur, instansi terkait, dan sumber lainnya meliputi tinjauan pustaka dan gambaran umum Subak.

\subsection{Variabel dan Pengukuran}

Variabel digunakan untuk mengetahui elemen-elemen subak sebagai sistem sosial di Subak Munggu Tegal Lantang. Elemen-elemen sistem sosial tersebut akan diketahui dengan melihat 10 indikator, yaitu tujuan, kepercayaan, perasaan atau sentimen, norma, sanksi, kedudukan dan peranan, kekuasaan, jenjang sosial atau pelapisan sosial, fasilitas, dan wilayah.

\subsection{Analisis Data}

Analisis data merupakan proses mencari dan menyusun secara sistematis data yang diperoleh dari hasil wawancara, catatan lapangan, dan dokumentasi (Sugiyono 2010).Data yang terkumpul dalam penilitian ini akan dianalisis dengan menggunakan metode analisis deskriptif kualitatif. Data yang diperoleh dari hasil penelitian berupa data kualitatif dan kuantitatif akan disajikan dalam bentuk narasi dan tabel yang disusun secara sistematis dan efisien. Analisis ini di bantu dengan dengan menggunakan metode skoring dalam mengukur variabel penelitian. Skor 1 merupakan skor minimum dan skor 5 merupakan skor maksimum. Skor yang telah diperoleh selanjutnya akan didistribusikan dalam kategori atau kelas dengan menggunakan rumus interval kelas. Kategori elemen-elemen subak Munggu Tegal Lantang dapat dirumuskan pada Tabel 1. 
Tabel 1.

Kategori Elemen/Sub Sistem Subak Munggu Tegal Lantang

\begin{tabular}{lcl}
\hline No & Presentase pencapaian skor & KategoriElemen Sub Sistem Sosial \\
\hline 1 & $20-36$ & Sangat rendah \\
2 & $>36-52$ & Rendah \\
3 & $>52-68$ & Sedang \\
4 & $>68-84$ & Tinggi \\
5 & $>84-100$ & Sangat Tinggi \\
\hline
\end{tabular}

\section{Hasil dan Pembahasan}

Berdasarkan hasil penelitian tingkat eksistensi elemen-elemen subak sebagai sistem sosial di Subak Munggu Tegal Lantang termasuk dalam kategori sangat tinggi dengan pencapaian skor $85,86 \%$. Pencapaian skor dari unsur-unsur elemen subak dapat dilihat pada Tabel 2.2.

Tabel 2.

Tingkat Eksistensi Elemen-Elemen Subak Sebagai Sistem Sosial di Subak Munggu

Tagal Lantang, Desa Perenan, Kecamatan Mengwi, Kabupaten Badung

\begin{tabular}{|c|c|c|c|c|}
\hline \multirow[t]{2}{*}{ No } & \multirow{2}{*}{$\begin{array}{c}\text { Indikator Elemen-Elemen } \\
\text { Subak } \\
\text { (Pendekatan Sosiologis) }\end{array}$} & \multicolumn{2}{|c|}{ Pencapaian Skor } & \multirow{2}{*}{$\begin{array}{l}\text { Kategori Elemen- } \\
\text { Elemen Subak }\end{array}$} \\
\hline & & Skor & $(\%)$ & \\
\hline 1 & Tujuan Subak & 4,48 & 89,70 & Sangat Tinggi \\
\hline 2 & Kepercayaan Subak & 4,48 & 89,70 & Sangat Tinggi \\
\hline 3 & Perasaan Subak & 3,64 & 72,73 & Tinggi \\
\hline 4 & $\begin{array}{l}\text { Norma (Awig-Awig dan } \\
\text { Pararem) Subak }\end{array}$ & 4,45 & 89,09 & Sangat Tinggi \\
\hline 5 & Sanksi Subak & 4,32 & 86,46 & Sangat Tinggi \\
\hline 6 & $\begin{array}{l}\text { Kedudukan dan Peranan } \\
\text { Subak }\end{array}$ & 4,51 & 90,15 & Sangat Tinggi \\
\hline 7 & Kekuasaan Subak & 4,20 & 84,04 & Sangat Tinggi \\
\hline 8 & Jenjang Sosial Subak & 4,46 & 89,29 & Sangat Tinggi \\
\hline 9 & Fasilitas Subak & 3,86 & 77,17 & Tinggi \\
\hline 10 & Wilayah Subak & 4,52 & 90,30 & Sangat Tinggi \\
\hline & $\begin{array}{l}\text { Eksistensi Elemen-Elemen } \\
\text { Subak }\end{array}$ & 4,30 & 85,86 & Sangat Tinggi \\
\hline
\end{tabular}

Penjabaran dari masing-masing tingkat eksistensi elemen-elemen subak di Subak Munggu Tegal Lantang, dapat dilihat pada uraian sebagai berikut.

\subsection{Tujuan Subak}

Tujuan diartikan sebagai suatu gambaran hasil yang diharapkan dan ingin dicapai (Sudarta dan Dharma, 2012). Berdasarkan hasil penelitian di Subak Munggu 
Tegal Lantang, eksistensi elemen subak pada unsur tujuan tergolong sangat tinggi, dengan pencapaian persentase skor $89,70 \%$.

Beberapa parameter dari tujuan subak yakni tujuan Subak Munggu Tegal Lantang untuk mempertahankan kelestarian subak dirumuskan secara tertulis termasuk dalam kategori sangat tinggi dengan skor $89,70 \%$. Hal itu dikarenakan untuk mempertahankan kelestarian subak memang pada umumnya telah dirumuskan dan merupakan hal yang diharapkan oleh seluruh anggota subak.

Tujuan Subak Munggu Tegal Lantang untuk mempertahankan kelestarian subak diketahui oleh seluruh anggota subak termasuk dalam kategori sangat tinggi dengan pencapaian skor 90,91\%. Hal ini disebabkan pimpinan subak selalu memperingatkan bahwa keberadaan subak harus terus dilestarikan. Tujuanpribadi anggota subak sejalan dengan tujuan subak dalam mempertahankan kelestarian subak termasuk dalam kategori sangat tinggi dengan skor 88,48\%. Hal tersebut disebabkan anggota subak memiliki inisiatif untuk terus mempertahankan kelestarian subak.

\subsection{Kepercayaan Subak}

Kepercayaan merupakan pernyataan tentang apa-apa yang diterima sebagai kebenaran sejati yang dipakai sebagai landasan untuk mencapai tujuan kelompok (Sudarta dan Dharma, 2012).Berdasarkan hasil penelitian pada Subak Munggu Tegal Lantang eksistensi elemen subak pada unsur kepercayaan Subak Munggu Tegal Lantang dalam mempertahankan dan menjaga kelestarian subak termasuk dalam kategori sangat tinggi dengan pencapaian skor 90,30\%.

Beberapa parameter menunjukkan kepercayaan subak yang bersifat irasional (anggota subak percaya bahwa adanya bangunan suci dan setiap upacara yang dilakukan subak mampu mempertahankan kelestarian subak) termasuk dalam kategori sangat tinggi dengan skor 90,91\%. Hal tersebut dikarenakan berbagai ritual dan kegiatan keagamaan di Subak dilakukan secara rutin oleh anggota subak untuk menjaga keharmonisan dan hubungan antara manusia dengan Tuhan Yang Maha Esa.

Parameter kepercayaan subak yang bersifat rasional (adanya teknologi atau inovasi pertanian yang dapat mempercepat proses pengolahan sehingga petani tidak memiliki keinginan untuk menjual lahan sawahnya) termasuk dalam kategori sangat tinggi dengan pencapaian skor $88,48 \%$. Hal ini disebabkan anggota subak mampu mempertahankan kelestarian subak dengan memanfaatkan teknologi ataupun mengadopsi berbagai inovasi pertanian yang ada.

\subsection{Perasaan Subak}

Orang-orang yang memiliki persamaan kebudayaan dan adat istiadat menyebabkan mereka mempunyai perasaan yang lebih dekat dan akrab (Suyatna, 1982). Berdasarkan hasil penelitian pada Subak Munggu Tegal eksistensi elemen subak pada unsur perasaan, subak termasuk dalam kategori tinggi dengan skor 72,73\%. Beberapa parameter menunjukkan anggota subak merasa senasib sebagai petani sawah termasuk dalam kategori sangat tinggi dengan pencapaian skor $87,88 \%$. 
Hal ini dikarenakan antara anggota subak merasa bahwa kehidupan mereka merata menjadi petani sawah.

Anggota subak memiliki tujuan atau kepentingan yang sama untuk mempertahankan kelestarian subak termasuk dalam kategori sangat tinggi dengan skor $88,48 \%$. Hal ini terjadi dikarenakan kesamaan pendirian dari masing-masing anggota subak untuk tetap bertanggung jawab dalam melestarikan subak.

Anggota subak memiliki kebudayaan yang sama termasuk dalam kategri rendah dengan skor $41,82 \%$. Hal itu disebabkan oleh ketidakseragaman kebudayaan antara anggota subak yang satu dan yang lain. Subak Munggu Tegal Lantang memiliki dua anggota yang menganut agama Kristen sedangkan sisanya menganut keyakinan Agama Hindu. Selain itu tidak semua anggota subak berasal dari Desa Pererenan, terdapat 20 anggota yang berasal dari luar Desa Pererenan.

\subsection{Norma Subak}

Norma merupakan suatu peraturan-peraturan mengenai kelakuan atau perbuatan yang berdasarkan pertimbangan-pertimbangan kesuliaan, kebiasaan, dan faham yang sehat. Bentuk dari norma ada yang tertulis dan ada juga yang tidak tertulis (Sudarta dan Dharma, 2012).Berdasarkan hasil penelitian pada Subak Munggu Tegal Lantang dalam mempertahankan kelestarian subak maupun eksistensinya, indikator norma pada subak termasuk dalam kategori sangat tinggi dengan pencapaian skor $89,09 \%$.

Beberapa parameter norma seperti Norma (awig-awig) subak dinyatakan secara tertulis/formal termasuk dalam kategori sangat tinggi dengan pencapaian skor 89,09\%. Hal ini dikarenakan Subak Munggu Tegal Lantang menyatakan bahwa subak perlu dilestarikan sehingga eksistensinya tetap terjaga.

Norma (awig-awig dan pararem)diketahui oleh seluruh anggota subak termasuk dalam kategori sangat tinggi dengan skor 90,30\%. Anggota subak taat pada norma (awig-awig dan pararem) termasuk dalam kategori sangat tinggi dengan skor $88,48 \%$, Hal ini dikarenakan anggota subak memiliki kesadaran tersendiri akan pentingnya mentaati norma yang ada di Subak Munggu Tegal Lantang. Selain itu beberapa responden mengungkapkan bahwa mereka malu untuk melanggar norma dikarenakan memang individu-individu yang menjadi anggota subak sebagian besar jarang ada yang melanggar norma,

Pada norma pekaseh subak mengingatkan dan menjelaskan norma kepada anggotatermasuk dalam kategori sangat tinggi dengan skor 88,48\%. Hal tersebut disebabkan pada setiap rapat pekaseh subak selalu mengingatkan akan norma umum yang memang seharusnya ditaati oleh seluruh anggota.

\subsection{Sanksi Subak}

Sanksi dapat diartikan sebagai suatu pemberian ganjaran atau hukuman kepada anggota kelompok, karena dipatuhi atau dilanggarnya norma kelompok. Sanksi merupakan bentuk operasional dari norma(Suyatna, 1982). 
Hasil penelitian Subak Munggu Tegal Lantang, eksistensi elemen subak pada unsur sanksi termasuk dalam kategori sangat tinggi dengan skor 86,46\%. Subak Munggu Tegal Lantang memiliki sanksi didalam norma tertulis dan tidak tertulis.

Beberapa parameter sanksi seperti menunjukkan norma (awig-awig) dilengkapi dengan sanksi yang jelas bagi anggota subak yang melakukan pelanggaran norma termasuk dalam kategori sangat tinggi dengan skor $86,06 \%$. Hal ini dikarenakan pada norma tertuang sanksi bagi setiap anggota yang melakukan pelanggaran norma. Pada sanksi dipahami dan ditaati oleh seluruh anggota subak termasuk dalam kategori sangat tinggi dengan skor 89,09\%.

Pada sanksi terkait pimpinan subak mengawasi dan mengenakan sanksi dengan tegas juga termasuk dalam kategori sangat tinggi dengan skor 84,24\%. Hal tersebut dikarenakan pekaseh subak nantinya akan mengenakan sanksi apabila ada anggota subak yang melakukan pelanggaran norma dan secara tidak langsung pekaseh subak tetap mengawasi sanksi yang tercantum dalam norma di Subak Munggu Tegal Lantang.

\subsection{Kedudukan dan Peranan}

Hasil penelitian pada Subak Munggu Tegal Lantang, eksistensi elemen subak pada unsur kedudukan dan peranan termasuk dalam kategori sangat tinggi dengan skor $90,15 \%$. Beberapa parameter seperti anggota berperan untuk mempertahankan eksistensi subak sesuai dengan kedudukannya termasuk dalam kategori sangat tinggi dengan skor 90,91\%. Hal itu dikarenakan anggota subak di Munggu Tegal Lantang memang masing-masing memiliki peran untuk mempertahankan eksistensi subak. Adanya koordinasi dan kerjasama secara internal dan eksternal subak untuk mempertahankan eksistensi subak termasuk dalam kategori sangat tinggi dengan skor 90,30\%. Hal ini dapat dilihat dalam bentuk kerjasama dan gotong royong yang dilakukan oleh anggota subak dan pekaseh subak selalu melakukan koordinasi dengan anggota maupun instansi terkait untuk dapat menguatkan lembaga subak.

Anggota subak memiliki keinginan untuk mempertahankan eksistensi subak sesuai dengan kedudukan dan peran yang dijalankan temasuk dalam kategori sangat tinggi dengan skor $90,91 \%$. Anggota-anggota subak mengungkapkan seluruh pihak memiliki keinginan dan bertekad untuk terus mempertahankan kelestarian subak.

Peranan yang dijalankan sesuai dengan status yang dimiliki termasuk dalam kategori sangat tinggi juga, dengan skor $88,48 \%$. Hal ini dikarenakan seluruh pihak baik anggota maupun pengurus di subak telah menjalankan kewajibannya sesuai dengan status dan fungsi yang dimilikinya.

\subsection{Kekuasaan}

Kekuasaan adalah kemampuan untuk mempengaruhi prilaku orang lain yakni menguasasi, memerintah, dan mengawasi orang lain termasuk mengambil keputusan mengenai sesuatu untuk melaksanakan sesuatu kegiatan yang diinginkan (Suyatna, 
1982). Hasil penelitian Subak Munggu Tegal Lantang, eksistensi elemen subak pada unsur kekuasaan termasuk kategori sangat tinggi dengan pencapaian skor 84,04\%.

Beberapa parameter seperti pemimpin atau pimpinan subak mampu menggerakkan anggota subak untuk mempertahankan eksistensi subak termasuk dalam kategori sangat tinggi dengan skor $84,24 \%$. Mempertahankan eksistensi subak sejauh ini tidak semata-mata digerakkan oleh pekaseh subak saja, akan tetapi didukung dengan kesadaran dari masing-masing anggota subak.

Pemimpin subak mampu mengambil keputusan dan kebijakan termasuk dalam kategori sangat tinggi dengan skor $86,06 \%$. Hal ini disebabkan pekaseh subak terlihat mampu mengambil keputusan maupun kebijakan dikarenakan dalam sebuah pertemuan terkait dengan membahas suatu permasalahan maupun hal-hal yang perlu dibicarakan. Pada kekuasaan pemimpin atau pimpinan subak mampu mengendalikan anggota subak juga memiliki kateogri sangat tinggi dengan pencapaian skor $81,82 \%$. Pekaseh subak mampu mengendalikan anggota subak dalam berbagai hal penting yang memang perlu dilakukan untuk mempertahankan kelestarian subak serta mencapai tujuan yang diinginkan. Hal tersebut misalnya pengendalian dalam hal ketaatan untuk mentaati norma dan pengendalian dalam hal pemeliharaan lahan dan kawasan di Subak.

\subsection{Jenjang Sosial Subak}

Jenjang sosial adalah kedudukan yang menunjukkan tingkat prestise atau kekuasaan yang membedakan anggota yang satu dengan anggota yang lain dalam suatu kelompok (Suyatna, 1982). Hasil penelitian pada Subak Munggu Tegal Lantang, eksistensi elemen subak pada unsur jenjang sosial termasuk dalam kategori sangat tinggi dengan pencapaian skor $89,29 \%$.

Beberapa parameter anggota subak memiliki sistem penjenjangan yang jelas termasuk dalam kategori sangat tinggi dengan pencapaian skor 89,70\%. Subak Munggu Tegal Lantang memiliki struktur organisasi yang jelas dan berbagai tugas dan kewajiban telah dijalankan sesuai dengan peranannya.

Penjenjang yang ada merupakan sumber motivasi untuk kemajuan termasuk dalam kategori sangat tinggi dengan pencapaian skor 90,30\%. Hal ini dikarenakan pengurus subak di Munggu Tegal Lantang merupakan orang-orang yang sesungguhnya memiliki kemampuan berkomunikasi, berjiwa inovatif, berpikir terbuka, dan mampu mengadopsi teknologi pertanian. Sistem penjenjangan dipahami oleh anggota subak juga memiliki kategori yang sangat tinggi dengan pencapaian skor $87,88 \%$. Hal tersebut dikarenakan pada pemilihan dan pembentukan struktur organisasi subak dibuat dan dipilih pada saat diadakannya rapat subak.

\subsection{Fasilitas Subak}

Fasilitas adalah segala alat atau sarana yang diperlukan untuk mencapai tujuan kelompok. Suatu kelompok tidak akan bisa mencapai tujuan secara efisien dan efektif, (Suyatna, 1982). Hasil penelitian pada Subak Munggu Tegal Lantang, 
eksistensi elemen subak pada unsur fasilitas subak termasuk dalam kategori tinggi dengan pencapaian skor $77,17 \%$.

Beberapa parameter dari fasilitas seperti Subak memiliki fasilitas fisik irigasi maupun non fisik irigasi serta kemudahan lain termasuk dalam kategori sedang dengan skor 53,33\%. Hal ini disebabkan Subak Munggu Tegal Lantang tidak memiliki koperasi akibat sulitnya perijinan dan kurangnya SDM untuk dijadikan pengurus di koperasi subak.

Seluruh anggota subak mampu memanfaatkan fasilitas yang terdapat dalam subak untuk mempertahankan eksistesi subak termasuk dalam kategori sangat tinggi dengan skor $88,48 \%$. Hal ini dikarenakan keberadaan fasilitas fisik irigasi dan nonfisik irigasi masih berfungsi dengan baik. Selain itu juga didukung oleh kemampuan anggota subak memelihara fasilitas dengan baik yang masuk dalam kategori sangat tinggi dengan skor $89,70 \%$.

\subsection{Wilayah Subak}

Wilayah adalah sebagai suatu ruang, tempat sistem sosial bertahan dan bergiat untuk mencapai tujuan yang diinginkan (Sudarta dan Dharma, 2012). Hasil penelitian pada Subak Munggu Tegal Lantang, eksistensi elemen subak pada unsur wilayah subak memiliki kategori sangat tinggi dengan pencapaian skor 90,30\%.

Beberapa parameter dari wilayah seperti Subak memiliki wilayah dengan batas-batas yang jelas termasuk dalam kategori sangat tinggi dengan pencapaian skor 90,91\%. Hal ini disebabkan anggota Subak Munggu Tegal Lantang setuju subak ini memiliki wilayah dengan batas-batas yang jelas.

Subak mampu memanfaatkan wilayah atau lahan subak termasuk dalam kategori sangat tinggi dengan pencapaian skor 90,30\%. Hal ini dikarenakan seluruh elemen subak mampu memanfaatkan wilayah subak sebagai tempat bercocok tanam dan mampu memperoleh pendapatan dari produktivitas pertanian.

Subak mampu mempertahankan dan mengamankan wilayah atau lahan subak juga memiliki kategori yang sangat tinggi dengan pencapaian skor $89,70 \%$. Hal itu terbukti dari kemampuan subak mengamankan wilayah dalam mengatasi seranganserangan hama yang terjadi dan subak mampu meminimalisir adanya alihfungsi lahan di wilayah Subak Munggu Tegal Lantang yang rentan akan adanya pembangunan-pembangunan di sektor pariwisata yang lebih menjanjikan.

\section{Simpulan dan saran \\ 4.1 Simpulan}

Tingkat eksistensi elemen-elemen subak sebagai sistem sosial memiliki kategori sangat tinggi sebesar 85,86\%, sehingga Subak Munggu Tegal Lantang mampu mempertahankan eksistensinya di tengah kawasan pariwisata. Beberapa dari parameter subak masih terlihat lemah dengan kategori rendah seperti pada parameter dalam indikator perasaan dan fasilitas. 


\subsection{Saran}

1. Pada norma (awig-awig dan pararem)dan sanksiperludituangkan suatu larangantentang alihfungsi lahan, mengingat Desa Pererenan merupakan kawasan pariwisata yang marak dengan adanya suatu alihfungsi. Larangan tersebut tentunya dapat menjadi faktor pendukung dalam mempertahankan eksistensi elemen-elemen subak yang otomatis mampu mempertahankan kelestarian dari subak itu sendiri.

2. Memperbaiki elemen-elemen sistem sosial yang masih lemah menjadi elemenelemen yang lebih baik lagi, elemen fasilitas perlu didukung lagi dengan didirikannya koperasi subak yang dapat mempermudah anggota subak untuk menjalankan kegiatan usahataninya.

3. Selalu memperhatikan keamanan serta mengantisipasi adanya permasalahan berupa serangan-serangan hama di Subak Munggu Tegal Lantang.

\section{Ucapan Terima Kasih}

Terimakasih kepada seluruh pihak yang telah memberikan pengarahan, bimbingan dan motivasi dalam penyelesaian penelitian dan penulisan jurnalini. Semoga penelitian ini dapat bermanfaat sebagaimana mestinya.

\section{Daftar Pustaka}

Arikunto, Suharsimi. 2003. Prosedur Penelitian, Suatu Praktek. Jakarta:Bina Aksara. Arikunto, Suharsimi. 2006. Prosedur Penelitian Suatu Pendekatan Praktik. Yogyakarta: Rineka Cipta.

Kuncoro. 2013. BAB III Metode Penelitian. Internet. (Artikel on_line). http://repository.unhas.ac.id/bitstream/handle/123456789/1717/BAB\%20III.d ocx? sequence=4. Diunduh pada tanggal 16 Januari 2015.

Pitana, I Gde. 1993. Subak, Sistem Irigasi Tradisional di Bali. Upada Sastra.Denpasar.

Pitana, I Gde, 2003. Rice-Based Culture and Tourism Development in Bali. Jurnal Dinamika Kebudayaan Vol.V No. 3: |15-121. Universitas Udayana.

Sudarta, Wayan, dan Dharma Putu, 2012. Laporan Kaji Tindak Implementasi Elemen-Elemen Subak Sebagai Sistem Sosial (Kasus Subak Anggabaya, Kecamatan Denpasar Timur, Kota Denpasar). Kerjasama Dinas Kebudayaan Kota Denpasar dengan Program Ekstensi Fakultas Pertanian Universitas Udayana.

Sugiyono 2010. Metode Penelitian Bisnis. Bandung : Penerbit Alfabeta.

Sutawan, Nyoman. 2008. Organisasi dan Manajemen Subak di Bali. Denpasar. Pustaka Bali Post.

Suyatna, I Gde, (1982). Ciri-Ciri Kedinamisan Kelompok Sosial Tradisional di Bali dan Peranannya dalam Pengembangan Disertasi, IPB, Bogor.

Windia, W. 2006. Transformasi Sistem Irigasi Subak yang Berlandaskan Tri Hita Karana. Denpasar. 